\title{
Hedge funds: A summary of the literature
}

Received (in revised form): 27th October, 2006

\section{Greg N. Gregoriou}

is Associate Professor of Finance at State University of New York at Plattsburgh and Hedge Fund Editor for Derivatives Use, Trading and Regulation.

\section{Neal E. Duffy}

is Associate Professor of Economics at State University of New York (Plattsburgh).

\begin{abstract}
The authors survey numerous hedge fund studies related to their institutional, historical and performance characteristics; their purpose and effectiveness in achieving balanced portfolios and the relationship of returns to manager skill, style, size and other characteristics. Also, a survey of statistical difficulties frequently encountered in evaluating databases of companies specialising in hedge funds including survival, selection and other biases; management selection methods and statistical methodologies used in asset selection for hedge funds and fund of funds is addressed. Pensions (2006) 12, 24-32. doi:10.1057/palgrave.pm.5950042
\end{abstract}

Keywords: hedge funds, portfolio management, correlation, performance, survival analysis, data biases, portfolio allocation

\section{Introduction}

The term 'hedge fund' was first used in 1949 by Alfred Winslow Jones to describe a private investment partnership whereby he 'hedged' the risk of his fund by purchasing undervalued stocks and shorting overvalued stocks. ${ }^{1,2}$ Jones created a market-neutral fund; by gearing his position, he was able to outperform the average US equity mutual fund. ${ }^{3,4}$ With the speculative attack by George Soros on the British pound in 1992 and the collapse of long-term capital management (LTCM) in 1998, hedge funds have received a great deal of coverage in professional and in academic journals.

Considered as absolute return and alternative investment vehicles, hedge funds have certain characteristics that mutual funds do not have at their disposal. The general approach traditionally

Correspondence: Greg N. Gregoriou, 101 Broad Street, Plattsburgh, New York 12901, USA.

Tel: +1518564 4202;

Fax: +1 5185644215 ;

Email: greg.gregoriou@plattsburgh.edu used by hedge fund managers is to find and invest in funds that have low or negative correlation with traditional stock, bond and currency markets. By offsetting market movements, hedge funds can improve a portfolio's risk-return relationship and decrease kurtosis, ${ }^{5,6}$ especially during periods of negative equity returns. ${ }^{7,8}$ Traditional asset classes such as stocks and bonds offer lower diversification advantages and tend to be highly correlated with US equity markets. ${ }^{9}$

Participation in hedge funds is restricted to high net-worth individuals and to institutional investors such as foundations, life insurance companies, endowments and investment banks. Unlike other traditional investments such as mutual funds, hedge funds are not currently regulated by the Securities Act of 1933 and are not required to disclose their positions. The US Court of Appeals has also recently invalidated the Securities and Exchange Commission's (SEC) attempt to regulate hedge funds under the Investment Advisers Act of 1940. Onshore funds are limited to accredited or sophisticated investors with a net worth exceeding $\$ 1 \mathrm{~m}$, but a fund of 
hedge funds (a basket of hedge funds) is not as restrictive. Hedge fund managers are paid an incentive fee based on performance, whereas mutual fund managers are compensated for the amount of assets they gather from investors.

Hedge funds are perhaps viewed as illiquid, absolute private investment vehicles that take advantage of price inefficiencies and market trends in financial markets. According to the Investment Advisers Act of 1940 and the Securities Exchange Act of 1934, private investment pools such as hedge funds are restricted to a maximum of 499 investors and are not able to issue public securities. Many hedge funds, however, form offshore funds as a mirror image of their onshore funds to attract additional investors.

Rather than comparing themselves to a benchmark, hedge funds typically focus on absolute returns in all market conditions. ${ }^{10,11}$ If the hedge fund's strategy is to uncover assets possessing low correlation to stock markets, the fund is labelled 'non-directional' (ie marketneutral and event-driven), while a strategy having high correlation to stock markets is 'directional' (ie global macro, long only and short sellers). ${ }^{12}$ Brunel $^{13}$, however, prefers to describe them as 'absolute return' or 'semi-directional' strategies.

\section{Size of industry}

How large is the hedge fund industry? The number of hedge funds and the total amount of capital under management is considered problematic. Hedge funds are unregulated, and no official government sources of data exist, thereby forcing investors to rely on private database vendors. Hedge funds typically display a higher attrition rate than mutual funds, as reported by Malkiel and Saha ${ }^{14}$, Brown et al. ${ }^{15}$ and by Liang, ${ }^{16}$ while some hedge funds have no communication with any database vendors. Chadha and Jansen ${ }^{4}$ observe that over 50 per cent of hedge funds refrain from submitting monthly performance figures to database vendors. Data in the hedge fund industry is collected on a monthly basis by database vendors such as ZCM/CISDM, HFR and TASS. All returns provided to the vendor are net of all management and performance fees.
Estimates of the number of hedge funds differ: Goldman Sachs and FRM ${ }^{17}$ estimates that there are more than 3,500 hedge funds in 1999, while Van Hedge $^{18}$ finds approximately 5,800 in existence with nearly $\$ 300$ bn under management. The President's Working Group on Financial Markets ${ }^{19}$ provides a range of 2,500-3,500 hedge funds existing in July 1998, and managing capital of $\$ 250 \mathrm{bn}$. It is very difficult to come to an exact conclusion, but when taking into account overlap, survivorship bias and non-reporting bias, there may be upwards of about 5,500 hedge funds in existence at June 2006 with $\$ 1.3$ tn of capital under management. ${ }^{20}$

What is certain is that both the number of hedge funds and industry assets have increased dramatically over the last ten years, starting from about 140 funds in $1968 .^{4}$ Stadlmann ${ }^{21}$ estimates total asset positions in the industry of around $\$ 4$ tn dollars at the end of 2001.

\section{Fund characteristics, performance and allocation percentage}

What has been the track record of hedge fund performance? Can they add value consistently? This is a crucial issue since some hedge funds have lock-up periods of up to two years and redemptions typically require a 30-, 60- or 90-day notice. Bares et al. ${ }^{22}$ find that persistence evaporates rapidly as the time-frame under investigation increases and further observe that absolute returns are sometimes unstable certain time periods. Amin and $\mathrm{Kat}^{5}$ observe that hedge funds do not offer a superior risk-return trade-off when non-normality is considered, while Fung et al. ${ }^{11}$ determine that survivorship bias all but eliminates absolute returns. Brown et al. ${ }^{15}$ examine US offshore hedge funds for the period 1989-1995 and find no persistence; however, they attribute it to style differences among classifications and conclude that there is a lack of managerial skill in the industry. On the other hand, Brorsen and Harri, ${ }^{23}$ use overlapping observations and find some support of performance persistence. Their study incorporates a longer time period and a larger dataset than the BGI and Agarwal and $\mathrm{Naik}^{24}$ studies. Conversely, Agarwal and Naik ${ }^{12}$ discover a reasonable amount 
of persistence when examining quarterly hedge fund returns, but persistence decreases as the time interval increases.

Schneeweis ${ }^{25}$ concludes that, on average, the volatility levels are more predictable than performance when investigating each hedge fund strategy and stresses that future performance is more dependable when using historical volatility than historical returns. He assumes that this may be due to (1) the long lock-up periods that somewhat prevents rebalancing, and (2) the majority of investors in hedge funds are institutions, pension funds and endowments, which have tendencies to be long-term investors. Schneeweis ${ }^{25}$ concludes that, on average, the volatility levels are more predictable than performance when investigating each hedge fund strategy and stresses that future performance is more dependable when using historical volatility than historical returns. Several studies use factor analysis to group hedge funds by style, to investigate the performance within each classification. $^{26-28}$

Ackermann et al. ${ }^{29}$ report that hedge funds do not always do better than stock market indices; however on a risk-adjusted return basis they outperform mutual funds. Their results suggest that hedge funds offer slight benefits as opposed to using index funds when risk-adjusted returns are considered, however, the low betas make hedge funds ideal for investor portfolios. AMR further determine that performance fees explain hedge fund performance. AMR further determine that performance fees explain hedge fund performance, but they do not find a significant relationship between performance and age, size. On the other hand Liang ${ }^{30}$ observes a positive correlation with performance fees, fund assets, and lock-up periods, but a negative impact for age. Fung et al. ${ }^{11}$ further observe that four factors explain hedge fund returns: management fees, fund size, fund age, and leverage.

\section{Correlation}

Fung and Hsieh ${ }^{31}$ find that hedge funds typically have low and in some cases negative correlation with traditional asset classes due to their dynamic strategies, and gearing as well as the constant change in asset allocation. Diz ${ }^{32}$ demonstrates that a well-balanced portfolio consisting of alternative investment strategies can yield a lower level of volatility by using a combination of equities, commodities, futures and hedge funds than just equities. Agarwal and $\mathrm{Naik}^{33}$ and Amin and $\mathrm{Kat}^{34}$ further demonstrate that combining various alternative investments and passive indexing can result in a better risk-return trade-off than only investing in passive different asset classes.

Schneeweis and Kazemi ${ }^{35,36}$ and Schneeweis et al. ${ }^{37}$ create optimised passive indices to investigate certain hedge fund strategies, but argue that nonnormal returns create problems if mean-variance optimisation is used. Certain problems still persist when indices attempt to track or mimic a hedge fund universe, however equally-weighted indices can offer enhanced diversification. ${ }^{38}$ Hedge fund strategies have low correlation with downturns in stock markets thereby minimizing downside risk, but in extreme negative market events their correlations increase significantly. ${ }^{7,31,39-43}$

While there are isolated cases of high correlation among some hedge fund strategies, it is well-known that a majority of hedge fund strategies traditionally have low correlation among themselves. This has led Schneeweis and Kazemi ${ }^{36}$ to praise the success of hedge funds to manager skill (alpha) and style selection. Within each hedge fund style, returns are determined by changes in the market environment and economic conditions, such as the adjustment of default spreads or the inherent volatility of a particular form of strategy. ${ }^{37,44}$

\section{Style analysis, manager skill and performance}

Does the superior performance of hedge funds have a relation to investment activity, or to managerial skill? Fung and $\mathrm{Hsieh}^{42}$ find no persistence in hedge fund returns, suggesting that returns have no relation with managerial skill. Goldman Sachs and FRM ${ }^{17}$ also report that managerial skill has no relationship with performance, and that newly created funds outperformed well-known hedge funds. What about size? The results are mixed, with Van Hedge $^{18}$ arguing that size is positively related to 
performance, while Gregoriou and Rouah ${ }^{45}$ find that performance of hedge funds and funds of hedge funds is not related to size. Agarwal et al. ${ }^{46}$ determine that hedge fund size is influenced by past performance, but that larger size ultimately leads to inferior performance.

The heterogeneity of hedge funds has caused Brune ${ }^{13}$ who finds it unwarranted to group hedge funds together, while $\mathrm{Lo}^{47}$ labels hedge funds not as a separate and distinct asset class, but to a certain extent as a "mongrel category". Fung and Hsieh ${ }^{31,42}$ use a multi-factor approach and Schneeweis and Spurgin ${ }^{7}$ use an extended Sharpe style analysis of eight classifications and five styles. The authors find that the five styles explain 45 per cent of hedge fund returns.

It is well-known that most hedge fund styles have negative skewness and high kurtosis. However, $\mathrm{Kat}^{48}$ finds that managed futures possess positive skewness and less kurtosis than the majority of other hedge fund classifications. To account for non-linearity Brown and Goetzmann $^{28}$ use a Generalized Classification algorithm and find that classification differences add approximately 20 per cent of the crosssectional variation in hedge fund performance. Bares et al. ${ }^{49}$ further present evidence on the style uniformity of hedge funds, using hard and fuzzy clustering. Park and Staum ${ }^{50}$ evaluate hedge funds by investigating the ratio of the manager's alpha (skill) to the information ratio in order to avoid difficulties encountered with the Sharpe and Treynor/Black ratios.

\section{Survival analysis}

Kouwenberg ${ }^{51}$ lists four reasons funds may drop out of a database: (1) no further requirement to attract new capital, (2) poor performance, (3) assets are returned to investors and 4) bankruptcy. How large of a problem is it? Brown et al. ${ }^{52}$ document that 50 per cent of hedge fund managers disappear within 30 months, while only 4 per cent had been in business for ten years. Gregoriou $^{53}$ finds that the median survival lifetimes of all hedge funds from 1990 to 2001 is 5.51 years using the ZCM database. Liang $^{54}$ finds an average of 8.54 per cent of funds vanish each year (13 per cent in 1998 alone), while
Kouwenberg ${ }^{51}$ using ZCM data finds an average of 15 per cent that disappear.

According to $\mathrm{BGP}^{52}$, the probability of survival is affected by investment style, size beta, and style consistency. The authors further notice a relationship between historical performance and risk levels of a fund, a result consistent with the Brown et al. (BHS) ${ }^{55}$ findings for mutual fund managers. Good performing hedge funds in the first half of the year usually decrease the volatility of their portfolios during the second half of the year, while poor performing funds in the first half of the year increase their volatility in the second half of the year.

Amin and $\mathrm{Kat}^{56}$ divide the HFR database into four groups and observe that hedge fund size is related to survival, with the smaller funds dying more rapidly. They also confirm that geared funds have higher attrition rates when compared to non-geared funds. Furthermore, Amin and $\mathrm{Kat}^{56}$ find that managers investing in their own fund did not have any impact on survival times. In the BHS study, the authors discover that excess volatility leads to fund closure and the newer the fund the more likely it is to drop out of the database.

\section{Random walks, cointegration, market timing, and size}

Gregoriou et al. ${ }^{57}$ determine that all hedge fund classes except a market-neutral category followed a random walk, and that most classes display evidence of a significant positive drift. In their follow-up study, Gregoriou and Rouah ${ }^{58}$ investigate the long-term relationships between the ten largest hedge funds in the ZCM/Laporte database and four stock market indices over a ten-year period. They find that three of the largest hedge funds were cointegrated with various market indices, while the remaining seven were not.

Gregoriou et al. ${ }^{59}$ then investigate the security selection and market-timing abilities of 1,494 hedge funds during the 1990-2000 period. Using a multi-index model designed to measure market timing and security selection in mutual funds, they discover that nearly all hedge fund styles exhibit poor market-timing skills, but that the 
majority possess good security selection abilities, a result consistent with the mutual fund literature. They also, however, find their results to be sensitive to the benchmark and market-timing model used. Within styles, they document evidence of a negative correlation between security selection and market-timing, but no correlation between returns and asset size or age. Gregoriou and Rouah ${ }^{60}$ also examine the returns of funds of hedge funds from 1994 to 1999 and observe that size does not affect performance. On the other hand, Agarwal et al. ${ }^{46}$ determine that they are first increasing, then decreasing returns associated with hedge fund size.

\section{Data biases}

The SEC restricts advertising by hedge funds; neither are they required to submit their returns to database vendors. This poses a problem for researchers, analysts, and academics who must understand the numerous sources of bias in the data $^{29,44}$ such as: (1) Selection bias is present when returns are not an accurate representation of the hedge fund universe. (2) Instant history bias is present when vendors backfill monthly returns of new funds entering the database. (3) Survivorship bias occurs if poor performing funds are discarded from the database. (4) Termination bias exists when funds shut down or voluntarily cease from reporting their returns. (5) Multiperiod sampling bias occurs when a hedge fund must have a sufficient amount of historical data before it can be added to the universe or sample.

The existence of such biases can considerably affect performance evaluation. Fung and $\mathrm{Hsieh}^{42}$ and Brown et al. ${ }^{15}$ have estimated that survivorship bias can explain the returns difference of 1.5-3 per cent per year. Fung et al. ${ }^{11}$ also assert that survivorship bias is of sufficient scale to negate any absolute returns. Conversely, Ackermann et al. ${ }^{29}$ maintain that survivorship bias and self-selection bias nullify each other. Selfselection bias frequently occurs when good performing hedge funds stop reporting their returns to database vendors in order not to attract additional capital that may actually hamper performance. For example, Tiger Management and the Soros Group of Funds experienced poor performance and fund size may have been the culprit. They were analogous to supertankers that could never port due to their enormous size. Tiger, with $\$ 18 \mathrm{bn}$ under management closed its doors in March of 2000, while Soros underwent restructuring and eliminated many of its funds and merged others. The once aggressive Soros approach to investing became more conservative.

Liang $^{16}$ investigates survivorship bias and observes that the overlap of databases is approximately 65 per cent, and that the difference in returns of the live funds and the returns of all the funds surpassed 2 per cent per year.

\section{Portfolio allocation of hedge funds}

Numerous large pension funds are beginning to accept hedge fund allocations of 5-20 per cent within their portfolios. ${ }^{61}$ CalPers (USA), one of the world's largest pension funds has allocated nearly $\$ 12 \mathrm{bn}$ of its $\$ 160 \mathrm{bn}$ fund to hedge funds. ${ }^{62}$ According to Watson, Wyatt and Indocam, ${ }^{63}$ European pension funds have increased their allocations to hedge funds by more than three-fold between 2000 and 2003. Endowment funds and institutional investors have also welcomed alternative investments with more eagerness than pension funds. This can be a result of the longer time frame of investing on the part of pension funds as well the liability of cash flow they require. The lock-up periods in the industry last one to three years thereby allowing a greater amount of management flexibility so the hedge fund manager's strategy can be executed without frequent interruptions and redemptions.

Sharpe ${ }^{64}$ asserts that an allocation of 10-20 per cent of alternative investments is ideal for pension funds. Amin and $\mathrm{Kat}^{34}$, find that optimum Sharpe ratios can be attained with a 10-20 per cent allocation to hedge funds within a traditional (S\&P 500) portfolio. In a traditional stock and bond portfolio an optimal allocation of 20 per cent to hedge funds is consistent with Liew ${ }^{65}$ and can augment the Sharpe ratio from 22.7 to 45.4 per cent.

\section{Fees and hurdle rates}

The fee structure and performance-based or incentive system of hedge funds are important 
drivers for superior performance. Hedge funds typically charge a management fee of 2 per cent and a performance fee of 20 per cent on capital appreciation, ${ }^{48}$ whereas funds of hedge funds usually charge a management fee of 1-2 per cent and a performance fee of 10 per cent. Most funds specify a 'high water mark' on their performance fees, assuring that in the event of poor performance, the fee will not be charged until prior losses are recuperated. Hurdle rates are intended to transmit a message of assurance to investors that their fund will experience high returns. Liang ${ }^{54}$ suggests that hedge funds in the ZCM database with hurdle rates have outperformed those without.

Agarwal et al. ${ }^{46}$ determine that money flows "chase" after good performance irrespective of high performance fees, but larger inflows are related with substandard future performance. They attribute this to a certain extent to a liquidity risk premium, since better performance is related with greater hindrance to capital withdrawals. Many managers habitually have money invested in their own funds, ensuring that their interests and those of their clients are better aligned (agency theory). The best performing funds set high standards that benefit investors, whereas underperforming funds are willing to lower their fees to attract more investors and increase their asset base. Numerous multi-manager hedge funds also charge front-load fees in addition to their management and performance fees.

\section{Funds of hedge funds}

Investors find that the selection of individual hedge funds is a risky, arduous and a burdensome task. However, investors can simply purchase into a 'fund of hedge funds' and obtain sufficient and instant portfolio diversification with less capital than directly investing into hedge funds. Funds of hedge funds combine hedge fund managers having various strategies so as to provide more consistent performance. ${ }^{45,61,66}$ But choosing 'star' hedge fund managers with great track records may also be too simplistic since past performance is not indicative of future performance. ${ }^{67} \mathrm{An}$ additional consideration is that although a multimanager fund with 25-100 underlying hedge fund managers would provide sufficient diversification, statistical theory suggests there is an asymptotic boundary as to the reduction of standard deviation. ${ }^{50,68,69}$ Any more than 25 managers does not provide additional benefits in terms of diversification. One study suggests that 15-25 hedge fund managers may provide sufficient diversification, ${ }^{70}$ while another purports that 5-10 managers may be sufficient. ${ }^{71}$ Larger numbers of hedge fund managers in a fund of hedge funds may eventually reduce diversification to the extent that styles may start overlapping. ${ }^{49}$

Institutional investors and pension funds stress the importance of on-site visits to examine back offices of hedge fund managers on a bi-monthly basis, to ensure they are adhering to their investment strategies. But if a fund of funds contains a high number of managers $(>50)$, it can be very difficult to regularly monitor the managers' investment strategies. ${ }^{70}$ Moreover, the aptitude to rapidly change market exposure and get in and out of positions quickly is easier with small funds of hedge funds, and difficult when there are 50-100 fund of hedge fund managers.

Funds of hedge funds have become a strong force in the hedge fund industry, accounting for more than 22 per cent of all funds in the hedge fund universe. They provide greater stability of returns, lower volatility and higher survival times than most hedge fund classifications. (The failure of LTCM in 1998 reminded investors of the importance of diversifying among different hedge fund managers, even at the expense of paying an extra layer of management and performance fees typically charged by fund of hedge funds.

Diversified funds of hedge funds with a global stance are the favorite among investors. ${ }^{72}$ with "Diversified funds of hedge funds with a global perspective are preferred by investors. ${ }^{72}$ Factor analysis and cointegration (especially for long/ short equity hedge funds) can be used to avoid including two or more managers with similar investment styles in a portfolio of hedge fund. ${ }^{73}$

The selection process generally requires that both qualitative and quantitative characteristics must be assessed. Picerno ${ }^{74}$ finds that 25 per cent of hedge fund managers had unethical and suspicious trading practices. In addition, funds of 
hedge funds are often non-transparent and do not disclose their positions or trading strategies to their investors. $\mathrm{Lo}^{47}$, however, stresses that the existence of transparency risk is the price to be paid for proprietary information (or manager skill) possessed by hedge fund and fund of hedge fund managers, which is the base of their performance-fee-reward structure. Howell ${ }^{75}$ suggests that hedge funds attain their best performance during their first two years of existence; however, the mortality rate of hedge funds peaks at 28 months.

\section{Statistical methodologies}

Common evaluation tools used in portfolio theory include the Sharpe ratio, the modified Sharpe ratio, Jensen's alpha, beta, covariance and the Sortino ratio. ${ }^{40}$ None of these measures in isolation can provide effective portfolio construction, performance evaluation or risk management. Tomlinson ${ }^{77}$ and Nawrocki ${ }^{78}$ have their reservations about using the standard deviation since gearing can artificially alter returns, some authors have advocated using the information ratio to account for gearing (alpha divided by the standard deviation).

Mean-variance analysis is also used extensively, often by using optimisers with built-in excel spreadsheet software that produce optimal portfolio allocations. Mean-variance optimisation assumes that returns are normally distributed, although hedge funds frequently employ options, leverage and market-timing results in fat tails due to their non-normal characteristics. Agarwal and Naik $^{78}$ use a modified approach by applying a passive option-based strategy to account for the difference in hedge fund returns, while Amenc et al. ${ }^{9}$ suggest that conditional betas should be used to explain the dynamic and non-normality characteristics of hedge fund risk.

Other measures of selecting hedge funds or fund managers are stress testing and back testing to find funds with low volatility and minimum drawdowns. Brunel ${ }^{13}$ proposes a simple objective function in evaluating hedge fund returns: Return - Volatility + Skewness - Kurtosis. Since hedge funds are often classified according to style, L'Habitant $^{79}$ suggests using index returns for separate hedge fund styles as appropriate benchmarks. In an effort to construct a more widespread explanation of hedge fund returns, Fung and $\mathrm{Hsieh}^{27}$ apply an asset-based style factor model, a là Fama and French's ${ }^{80}$ APT model.

\section{Conclusions}

The inclusion of hedge funds in portfolios represents a unique opportunity for institutional investors to protect their investments in bear markets. Rao and Szilagyi ${ }^{81}$ estimate that by 2006, $\$ 1.7$ th of capital will be invested in hedge funds. By the year 2000, hedge funds amassed as much as $\$ 1$ th in assets; however, they still only control only 4 per cent of the $\$ 25$ tn pensions, mutual funds, endowments funds and insurance industry assets. ${ }^{82}$ Kouwenberg ${ }^{51}$ finds that a majority of hedge funds have positive alphas, and Capocci and Hubner ${ }^{83}$ conclude that over 25 per cent of funds delivered positive and significant excess returns, while Amin and $\mathrm{Kat}^{34}$ observe that 72 of 77 hedge funds were not efficient as stand-alone investments when third and fourth moments were examined. Recently, Gregoriou et al. ${ }^{84}$ use data envelopment analysis as an alternative performance measure to investigate the efficiency and performance of hedge fund classifications. This technique should be used by FOF managers to help in hedge fund manager selection.

Still, most studies agree with the conclusion that a well-balanced portfolio containing hedge funds can provide superior long-term returns with lower volatility than one without hedge funds. If properly managed, hedge funds can provide effective safeguards during bear markets and periods of increased volatility. Finally, since hedge funds are considered illiquid investments, institutions wishing to invest in this alternative asset class must have a long-term outlook.

\section{References}

1 Lederman, J. and Klein, R. (1995) 'Hedge Funds: Investment and Portfolio Strategies for the Institutional Investor', Irwin Professional Publishing, New York, NY.

2 Temple, P. (2001) 'Hedge Funds: Courtesans of Capitalism', John Wiley and Sons, New York, NY.

3 Caldwell, T. and Kirkpatrick, T. (1995) 'A Primer on Hedge Funds', Lookout Mountain Capital, Inc, Chattanooga.

4 Chadha, B. and Jansen, A. (1998) 'The Hedge Fund Industry: Structure, Size and Performance', in Eichengreen, B., Mathieson, 
D., Chadha, B., Jansen, A., Kodres, L. and Sharma, S. (eds.) ‘ Hedge Funds and Financial, Dynamics', Chapter 3. International Monetary Fund, Washington, DC, pp. 27-41.

5 Amin, G. and Kat, H. M. (2002) 'Portfolios of hedge funds'. Working Paper, University of Reading, ISMA Centre, Reading, UK.

6 Schneeweis, T. and Spurgin, R. (1998) 'Skewness in asset returns: Does it matter', Journal of Alternative Investments, Vol. 1, No. 2, pp. 66-75.

7 Schneeweis, T. and Spurgin, R. (1998a) 'Alternative investments in institutional portfolios'. CISDM Working Paper Series, University of Massachusetts, Amherst, MA.

8 Könberg, M. and Lindberg, M. (2001) 'Hedge funds: A review of historical performance', Journal of Alternative Investments, Vol. 4, No. 1, pp. 21-32.

9 Amenc, N., Martellini, L. and Vaissie, M. (2003) 'Benefits and risks of alternative investment strategies', Journal of Asset Management, Vol. 4, No. 2, pp. 96-118.

10 Karolyi, G. (1999) 'Hedge funds: What they are and what they are not?'. Working Paper, Fisher College of Business, Columbus, $\mathrm{OH}$.

11 Fung, H., Xu, X. and Yau, J. (2004) 'Do hedge fund managers display skill?' The Journal of Alternative Investments, Vol. 6, No. 4, pp. 22-31.

12 Agarwal, V. and Naik, N. (1999) 'Multi-period performance persistence analysis of hedge funds', Journal of Financial and Quantitative Analysis, Vol. 35, No. 3, pp. 327-342.

13 Brunel, J. (2004) 'Revisiting the role of hedge funds in diversified portfolios', The Journal of Wealth Management, Vol. 6, No. 4, pp. 35-48.

14 Malkiel, B and Saha, A. (2005) 'Hedge funds: Risk and return', Financial Analysts Journal, Vol. 61, No. 6, pp. 80-88.

15 Brown, S., Goetzmann, W. N. and Ibbotson, R. (1999) 'Offshore hedge funds: Survival and performance 1989-1995', Journal of Business, Vol. 72, No. 1, pp. 91-117.

16 Liang, B. (2000) 'Hedge funds: The living and the dead', Journal of Financial and Quantitative Analysis, Vol. 35, No. 3, pp. 309-326.

17 Goldman, Sachs \& Co. and Financial Risk Management Ltd. (1999) 'The hedge fund industry and absolute return funds', The Journal of Alternative Investments, Vol. 1, pp. 11-27.

18 Van Hedge. (September 21, 1999) 'Number of hedge funds increases for tenth consecutive year. http://www.vanhedge.com/ size.htm.

19 President's Working Group Report on Financial Markets (2000) 'Sound Practices for Hedge Fund Managers', Washington, DC.

20 'Business Week'. 30th June, 2006.

21 Stadlmann, M. (2001) 'Hedge Funds and Absolute Returns', WestAM Management, London, UK.

22 Bares, P., Gibson, R. and Gyger, S. (2003) 'Performance in the hedge funds industry: An analysis of short-and long-term persistence', The Journal of Alternative Investments, Vol. 6, No. 3, pp 25-41.

23 Brorsen, B. and Harri, A. (2001) 'Performance persistence of hedge funds'. Working paper, Oklahoma State University, Stillwater, OK.

24 Agarwal, V. and Naik, N.Y. (2000a) 'Generalized style analysis of hedge funds', Journal of Asset Management, Vol. 1, No. 1, pp. 93-109.

25 Schneeweis, T. (1998a) 'Evidence of superior performance persistence in hedge funds: An empirical comment', Journal of Alternative Investments, Vol. 1, No. 2, pp. 76-79.

26 Fung, W. and Hsieh, D. A. (2002) 'Asset-based style factors for hedge funds', Financial Analysts Journal, Vol. 58, No. 5, pp. 16-27.
27 Fung, W. and Hsieh, D. A. (2004) 'Hedge fund benchmarks: A risk-based approach', Financial Analysts Journal, Vol. 60, No. 5, pp. 65-80.

28 Brown, S. and Goetzmann, W. N. (2001) 'Hedge funds with style'. Working Paper, New York University, New York, NY.

29 Ackermann, C., McEnally, R. and Ravenscraft, D. (1999) 'The performance of hedge funds: Risk, return and incentives', Journal of Finance, Vol. 54, No. 3, pp. 833-874.

30 Liang, B. (1999) 'On the performance of hedge funds', Financial Analysts Journal, Vol. 55, No. 4, pp. 72-85.

31 Fung, W. and Hsieh, D. A. (1997a) 'Empirical characteristics of dynamic trading strategies: The case of hedge funds', Review of Financial Studies, Vol. 10, No. 2, pp. 275-302.

32 Diz, F. (2001) 'Are investors over-invested in equities?' Derivatives Quarterly, Vol. 7, No. 3, pp. 59-62.

33 Agarwal, V. and Naik, N.Y. (2000c) 'On taking the alternative route: Risks, rewards, and performance persistence of hedge funds', Journal of Alternative Investments, Vol. 2, No. 4, pp. 6-23.

34 Amin, G. and Kat, H. M. (2003) 'Hedge fund performance 1990-2000: Do the “money machines" really add value?' Journal of Financial and Quantitative Analysis, Vol. 38, No. 2, pp. 251-274.

35 Schneeweis, T. and Kazemi, H. (2001a) 'The creation of alternative tracking portfolios for hedge fund strategies'. Working Paper, CISDM/SOM, University of Massachusetts, MA.

36 Schneeweis, T. and Kazemi, H. (2001b) 'Alternative Means of Replication Hedge Fund Manager Performance', CISDM/SOM, University of Massachusetts, Amherst, MA.

37 Schneeweis, T., Kazemi, H. and Spurgin, R. (2001) 'Volatility Factors and Hedge Fund Returns', CISDM/SOM, University of Massachusetts, Amherst, MA.

38 Fung, W. and Hsieh, D. A. (2000) 'Performance characteristics of hedge funds and commodity funds: Natural vs spurious biases', Journal of Financial and Quantitative Analysis, Vol. 353, pp. 291-307.

39 Martin, G. (2000) 'Making sense of hedge fund returns: What matters and what doesn't'. Working Paper, CISDM, University of Massachusetts, Amherst, MA.

40 Sortino, F. and van de Meer, R. (1991) 'Downside risk', Journal of Portfolio Management, Vol. 17, No. 4, pp. 27-31.

41 Schneeweis, T., Spurgin, G. and Potter, M. (1996) 'Managed futures and hedge fund investments for downside equity risk management', Derivatives Quarterly, Vol. 3, No. 1, pp. 62-72.

42 Fung, W. and Hsieh, D. A. (1997b) 'Survivorship bias and investment style in the returns of CTAs: The information content of performance track records', Journal of Portfolio Management, Vol. 24, No. 1, pp. 30-41.

43 Schneeweis, T. and Spurgin, G. (1998b) 'Multifactor analysis of hedge funds, managed futures and mutual fund return and risk characteristics', Journal of Alternative Investments, Vol. 1, No. 2, pp. $1-24$.

44 Fung, W. and Hsieh, D. A. (2001) 'Asset based hedge fund styles and portfolio diversification'. Working Paper, Duke University, Durham, NC.

45 Gregoriou, G. N. and Rouah, R. (2002b) 'Is size a factor in hedge fund performance', Derivatives Use, Trading \& Regulation, Vol. 7, No. 4, pp. 301-305.

46 Agarwal, V., Daniel, N. and Naik, N. Y. (2003) 'Flows, performance, and managerial incentives in hedge funds, European Finance Association Meeting, Glasgow.

47 Lo, A. (2001) 'Risk management for hedge funds: Introduction and overview', Financial Analysts Journal, Vol. 57, No. 6, pp. 16-33.

48 Kat, H. (2004) 'Managed Futures and Hedge Funds: A Match Made in Heaven', in Gregoriou, G., Karavas, V., Lhabitant, F., and 
Rouah, F., (eds.) ' Commodity Trading Advisors', John Wiley and Sons Inc., Hoboken, NJ.

49 Bares, P., Gibson, R. and Gyger, S. (2001) 'Style consistency and survival probability in the hedge fund industry'. Working Paper, Swiss Federal Institute of Technology, Geneva, Switzerland.

50 Park, J. and Staum, J. (1998) 'Fund of funds diversification: How much is enough?' Journal of Alternative Investments, Vol. 1, No. 3, pp. 29-42.

51 Kouwenberg, R. (2003) 'Do hedge funds add value to a passive portfolio? Correcting for non-normal returns and disappearing funds', Journal of Asset Management, Vol. 3, No. 4, pp. 361-382.

52 Brown, S., Goetzmann, W. N. and Park, J. (2001) 'Careers and survival: Competition and risk in the hedge fund and CTA industry', Journal of Finance, Vol. 56, No. 5, pp. 1869-1886.

53 Gregoriou, G. N. (2002) 'Hedge fund survival lifetimes', Journal of Asset Management, Vol. 3, No. 3, pp. 237-252.

54 Liang, B. (2001) 'Hedge fund performance: 1990-1999', Financial Analysts Journal, Vol. 57, No. 1, pp. 11-18.

55 Brown, S., Harlow, V. and Starks, L. (1996) 'Of tournaments and temptations: An analysis of managerial incentives in the mutual fund industry', Journal of Finance, Vol. 51, No. 1, pp. 85-110.

56 Amin, G. and Kat, H. (2001) 'Welcome to the dark side'. Working Paper, University of Reading, ISMA Centre, UK.

57 Gregoriou, G. N., Rouah, F. and Sedzro, K. (2001) 'Do hedge fund returns follow random walks?' Derivatives Use, Trading \& Regulation, Vol. 7, No. 3, pp. 241-250.

58 Gregoriou, G. N. and Rouah, F. (2001) 'Do stock market indices ten largest hedge funds? A cointegration approach', Journal of Alternative Investments, Vol. 4, No. 2, pp. 61-66.

59 Gregoriou, G. N., Rouah, F. and Sedzro, K. (2002) 'Market timing and security selection of hedge funds: 1990-2000', Derivatives Use, Trading \& Regulation, Vol. 8, No. 1, pp. 140-158.

60 Gregoriou, G. N. and Rouah, F. (2002b) 'The role of hedge funds in pension fund portfolios: Buying protection in bear markets', Journal of Pensions Management, Vol. 8, No. 3, pp. 237-245.

61 Gregoriou, G. N. and Rouah, F. (2002a) 'Pitfalls to avoid when constructing a fund of hedge funds', Derivatives Use, Trading $\mathcal{E}$ Regulation, Vol. 8, No. 1, pp. 59-65.

62 Chernoff, J. (2001) 'Pension funds want in on hedge fund action', Pension and Investments, Vol. 29, No. 2, pp. 3.

63 Watson Wyatt/ INDOCAM Survey (2000) 'Alternative Investment Review Relating to the Continental European Marketplace', London, UK.

64 Sharpe, W. (1992) 'Asset allocation: MANAGEMENT style and performance measurement', Journal of Portfolio Management, Vol. 18, No. 1, pp. 7-19.

65 Liew, J. (1999) 'Essays in Investment Strategies', UMI Dissertation Service, Ann Arbor, MI.
66 Gregoriou, G. (2000) 'Fund of funds: When more definitely means less', Canadian Business Economics Journal, Vol. 8, No. 2, pp. $83-85$.

67 Kahn, R. and Rudd, A. (1995) 'Does historical performance predict future performance?' Financial Analysts Journal, Vol. 51, No. 6, pp. 43-53.

68 Statman, M. (1987) 'How many stocks make a diversified portfolio?' Journal of Financial and Quantitative Analysis, Vol. 22, No. 3, pp. 353-368.

69 Evans, J. and Archer, S. (1968) 'Diversification and the reduction of dispersion: An empirical analysis', Journal of Finance, Vol. 23, No. 2, pp. 761-767.

70 Peskin, M., Urias, M., Anjilvel, S. and Boudreau, B. (2000) 'Why hedge funds makes sense', Quantitative Strategies, Morgan Stanley Dean Witter, New York, NY.

71 Henker, T. (1998) 'Naïve diversification for hedge funds', Journal of Alternative Investments, Vol. 1, No. 3, pp. 33-38.

72 Fothergill, M. and Coke, C. (2001) 'Fund of hedge funds', Journal of Alternative Investments, Vol. 4, No. 2, pp. 7-16.

73 Alexander, C. (2001) "Market Models', John Wiley and Sons Inc., New York NY.

74 Picerno, J. (November, 2001) 'The happy world of hedge funds', Bloomberg Wealth Manager, pp. 64-72.

75 Howell, M. (2001) 'Fund age and performance', Journal of Alternative Investments, Vol. 4, No. 2, pp. 57-60.

76 Tomlinson, B. (1999) "Why Standard Deviation is a Poor Measure of Risk', Financial Risk Management Ltd., London UK.

77 Nawrocki, D. (1999) 'A brief history of downside risk measures', Journal of Investing, Vol. 8, No. 3, pp. 9-26.

78 Nawrocki, D. (2000b) 'On benchmarking of hedge funds with passive and option-based strategies'. IFA Working Paper, London Business School, London, UK.

79 L'Habitant, F. (2001) 'Assessing market risk for hedge funds and hedge fund portfolios', Journal of Risk Finance, Vol. 2, No. 4, pp. $16-42$.

80 Fama, E. and French, K. (1992) 'The cross-section of expected stock returns', Journal of Finance, Vol. 47, No. 2, pp. 427-465.

81 Rao, R. and Szilagyi, J. (1998) 'The Coming Evolution of the Hedge Fund Industry: A Case for Growth and Restructuring', KPMG Peat Marwick, New York, NY.

82 Baily, M., Farrell, D. and Lund, S. (2000) 'The color of hot money', Foreign Affairs, Vol. 79, No. 2, pp. 99-109.

83 Capocci, D. and Hübner, G. (2004) 'Analysis of hedge fund performance', Journal of Empirical Finance, Vol. 11, No. 1, pp. $55-89$.

84 Gregoriou, G. N., Sedzro, K. and Zhu, J. (2005) 'Hedge fund performance appraisal using data envelopment analysis', European Journal of Operational Research, Vol. 164, No. 2, pp. 555-571. 